\title{
Metabolism of broilers subjected to different lairage times at the abattoir and its relationship with broiler meat quality
}

\author{
[Metabolismo de frangos de corte submetidos a diferentes tempos de espera no abatedouro \\ e sua relação com a qualidade da carne] \\ D.R. Rodrigues ${ }^{1}$, M.B. Café ${ }^{1}$, R.M. Jardim Filho ${ }^{2}$, E. Oliveira ${ }^{1}$, T.C. Trentin ${ }^{3}$, \\ D.B. Martins ${ }^{1}$, C.S. Minafra ${ }^{4}$ \\ ${ }^{1}$ Programa de pós-graduação - Escola de Medicina Veterinária e Zootecnia- Universidade Federal \\ de Goiás - UFG - Goiânia, GO \\ ${ }^{2}$ Universidade Federal de Goiás - UFG - Goiânia, GO \\ ${ }^{3}$ Programa de Residência - Universidade Federal de Goiás - UFG - Goiânia, GO \\ ${ }^{4}$ Instituto Federal Goiano - IF Goiano - Rio Verde, GO
}

\begin{abstract}
An investigation was made into the effects of different lairage times and the position of chicken crates during transport to the slaughterhouse on the biochemical and hematological profile and physical parameters of broilers, such as color and $\mathrm{pH}$ of their breast meat. The treatments were defined by the animals slaughtered after $0,2,4$ and 6 hours of lairage time at the slaughterhouse, transported in crates located in the top and bottom layers of the truck. It was found that increasing the lairage time at the slaughterhouse to over two hours reduced the number of lymphocytes and increased the heterophil/lymphocyte $(\mathrm{H} / \mathrm{L})$ ratio and the basophil count in the hemogram. In addition, lactate dehydrogenase (LDH) activity and cholesterol levels increased and plasma triglyceride and glucose levels decreased. The position of the crates in the truck altered the creatine kinase (CK) activity, and the highest enzyme activity was found in birds transported in the top layer of crates in the truck. Furthermore, the long lairage time in the slaughterhouse increased the $\mathrm{pH}$ and the value of $\mathrm{a}^{*}$ (redness value) and decreased the lightness value of breast fillets. The interaction significant between 4 and 6 hours of lairage time and the position of the crate in the top layer of the truck favored the development of dark, firm, dry (DFD) meat.
\end{abstract}

Keywords: animal welfare, DFD meat, fasting, holding sheds, pre-slaughter

\section{RESUMO}

Este trabalho objetivou a avaliação dos efeitos dos diferentes tempos de espera e da posição das caixas de transporte no caminhão sobre perfil bioquímico e hematológico, além de parâmetros físicos da carne, como cor e $\mathrm{pH}$ do peito, de frangos de corte. Os tratamentos foram definidos pelos animais abatidos com zero, duas, quatro e seis horas de espera no abatedouro, posicionados nas partes superior e inferior do caminhão. Como resultado, verificou-se que o aumento do tempo de espera no abatedouro, acima de duas horas, resultou em redução no número de linfócitos, elevação da razão heterófilos/ linfócitos $(H / L)$ e de basófilos no hemograma. Houve aumento da atividade de lactato desidrogenase (LDH), dos níveis de colesterol e redução de triglicerídeos e glicose no plasma. O posicionamento das caixas na parte superior da carroceria do caminhão elevou a enzima creatina quinase (CK) sanguínea. Além disso, o tempo prolongado na área de espera aumentou o $\mathrm{pH}$ final e o valor de * $^{*}$ (teor de vermelho) e diminuiu a luminosidade dos filés. A interação significante dos fatores tempo de espera de quatro e seis horas e a posição superior das caixas de transporte propiciaram o desenvolvimento de carnes duras, firmes e escuras (DFD) em frangos de corte.

Palavras-chave: bem-estar animal, carne DFD, galpão de espera, jejum, pré-abate

Recebido em 19 de setembro de 2016

Aceito em 10 de outubro de 2016

E-mail: veterinariadenise@ hotmail.com 


\section{INTRODUCTION}

Lairage times in poultry slaughterhouses usually range from 2 to 4 hours, but may vary considerably depending on the logistics and planning of the processing plant. Vieira et al. (2011), who reported pre-slaughter statistics for a Brazilian poultry processing plant, stated that the average lairage time was 2 hours and $58 \mathrm{~min}$, and the maximum was 17 hours and $38 \mathrm{~min}$.

Brazilian regulations generally recommend techniques for pre-slaughter handling that consider animal welfare (Brasil, 2000), but do not establish a specific standard lairage time in the poultry slaughterhouse (Brasil, 1998). With a view towards ensuring animal welfare and reducing losses in meat quality, Ludtke et al. (2010) recommend that the total fasting time for birds should not exceed 12 hours. However, in order to determine the total fasting time, one must take into account the pre-slaughter fasting strategy applied at the poultry farm, which should be at least 6 to 8 hours (Brazil, 1998), plus the distance from the farm to the abattoir, and the lairage time at the processing plant.

It is important that poultry be left in lairage sheds for the minimum time necessary to ensure the optimal flow of the slaughter operation and the animals' welfare, and the ideal recommended lairage time is one hour, and no more than two hours (Ludtke et al., 2010). Birds that are left waiting in the truck for too long may present high mortality rates (Nidjam et al., 2004) and dehydration, since they have no access to food and water (Ludtke et al., 2010).

As for lairage times at abattoirs, however, finding are still contradictory. Vieira et al. (2011) reported that it was necessary for broilers to be left for 3 to 4 hours in an air-conditioned lairage shed in order to reduce thermal load and mortality rate.

The different waiting times birds are subjected to in lairage sheds at processing plants increase their total fasting time and cause changes in their metabolism and in the physicochemical parameters of their meat (Nijdam et al., 2005; Bianchi et al., 2006). In addition, prolonging the fasting period leads to loss of live weight and to the multiplication of microorganisms such as Salmonella sp. in the crop and caecum (Burkholder et al., 2008).
Previous studies have reported poor poultry meat quality from Brazilian producers due to preslaughter stress (Langer et al., 2010; Kato et al., 2013). Variations in quality parameters are usually attributed to poor ante-mortem handling conditions and post-mortem metabolic changes. These physiological disorders trigger biochemical anomalies that affect the appearance, $\mathrm{pH}$, texture and juiciness of meat (Dadgar et al., 2012).

Given the above, the objective of this study is to investigate the effects induced by different lairage times and positions of chicken transportation crates on the metabolism of broilers, based on laboratory tests (blood count and biochemical profile) and the physical properties of their meat.

\section{MATERIAL AND METHODS}

The experiment was conducted in October 2014 in an abattoir in the municipality of Itaberaí-GO, in a region with an average altitude of $727 \mathrm{~m}$ located at the geographical coordinates of $16^{\circ}$, $35^{\prime}, 38^{\prime \prime} \mathrm{S}$ and $49^{\circ}, 17^{\prime}, 12^{\prime \prime} \mathrm{W}$.

This experiment involved 80 male Cobb broilers, which were raised starting as one-day-old chicks and were slaughtered at 44 days of age with a mean weight of $3.229 \mathrm{~kg} / \mathrm{bird}$. The stocking density was $13.67 \mathrm{birds} / \mathrm{m}^{2}$, corresponding to a total of 20,500 birds housed in the shed.

This study was approved by the Ethics Committee on Animal Use (CEUA) of the Federal Institute of Education, Science and Technology of Goiás (IFG), on 10 Feb 2014, under Protocol no. 03/2014.

The birds were distributed in eight treatments, with ten replicates each, in a completely randomized $4 \times 2$ factorial design (lairage times at the abattoir vs. position of crates in the truck). The lairage times were 0, 2, 4 and 6 hours, and the crates were positioned in the top and bottom layers in the center of the poultry truck. Total fasting times, corresponding to broiler fasting, catching and loading times at the farm, transport times, and lairage times at the abattoir, were $12 \mathrm{~h}$ and $40 \mathrm{~min}, 14 \mathrm{~h}$ and $40 \mathrm{~min}, 16 \mathrm{~h}$ and $40 \mathrm{~min}$, and $18 \mathrm{~h}$ and $40 \mathrm{~min}$. 
Fasting time at the farm was 8 hours. After this period, the birds were caught from behind, with at most two chickens per worker, and 8 birds were placed in each transport crate. The birds used in the experiment were placed in a single truck containing 510 transport crates, and the time spent in these operations was $2 \mathrm{~h}$ and 40 min. To standardize the experiment, the crates used in the test were placed at the rear of the truck, with eight crates in the top layer and eight in the bottom layer of the middle row of the poultry truck.

The poultry truck left the farm at about 5 a.m. and reached the slaughterhouse about 2 hours later, covering a distance of $110.2 \mathrm{~km}$. Lairage time was considered the period of time from the birds' arrival at the slaughterhouse until they were hung upside down by their legs. The lairage shed had a capacity for eight chicken transport trucks and was cooled by means of misting fans and lines.

Data on the environmental variables of temperature and relative humidity (RH) were collected in the waiting area at the slaughterhouse, using a digital thermohygrometer. The same variables were also checked inside the transport crates before unloading, using a thermo-hygrometer with attached probe.

Four birds transported in the top layer and four transported in the bottom layer of the truck were sampled for each lairage time, making a total of 32 sampled birds. For the sampling process, the crates located in the top layer of the truck were unloaded and placed in the slaughterhouse reception area. The birds in these crates were then tagged, blood was drawn from the brachial vein, and they were hung on the slaughter line. The birds unloaded from the bottom layer of the truck underwent the same procedure.

The hematological profile was obtained from a complete blood count (CBC) test performed manually. The cells were counted in a Neubauer chamber, using the Natt and Herrick method. To visualize the cell morphology and differentiate leukocytes, counts were performed on 100 cells stained by the rapid panoptic staining method (Laborclin®, Pinhais, PR), using light microscopy. The heterophil/lymphocyte $(\mathrm{H} / \mathrm{L})$ ratio was determined based on this analysis.
The serum biochemical levels were measured spectrophotometrically in a CM250 automatic biochemistry analyzer (Wiener $\AA$, Argentina), following the manufacturer's recommendations. The values were determined in duplicate, using commercial analytical kits (Biotécnica®, Varginha, MG).

The sampling unit used for the laboratory analysis of broiler meat quality, $\mathrm{pH}$ and color was the pectoralis major muscle, i.e., the breast meat. The color was determined by reading three parameters defined by the CIE-L*a*b* method at the Food Engineering Laboratory of the Federal University of Goiás (UFG). The color parameters of lightness $\left(\mathrm{L}^{*}\right)$, red $\left(\mathrm{a}^{*}\right)$ and yellow $\left(\mathrm{b}^{*}\right)$ content were measured using a colorimeter (ColorQuest II, Hunterlab®, USA). The readings, which were performed in quadruplicate, were taken after 24 hours of refrigeration. $\mathrm{pH}$ was measured with a digital $\mathrm{pH}$ meter for meat products (TESTO 205, TESTO $®$, Germany), with automatic temperature compensation. The final value obtained was the result of the measurements taken at three different points (cranial, caudal and mediolateral) of the sampling unit one hour and 24 hours post mortem.

The data on meat quality, and the hematological and biochemical parameters were subjected to an analysis of variance, and the average values were compared using the Tukey test at 5\%. When factor interaction was observed, the outcome was examined by Tukey's test at $5 \%$. The statistical program SAEG (Software Analysis and Experimentation Group) version 9.1 was used.

\section{RESULTS AND DISCUSSION}

Table 1 describes the environmental conditions inside the transport crates and in the climatized shed during the lairage times in the slaughterhouse.

In the experimental conditions, the variables of temperature and relative humidity $(\mathrm{RH})$ showed mean values lower than or equal to those considered comfortable $\left(26^{\circ} \mathrm{C}\right.$ and $\left.55 \%\right)$ for 6 week-old broilers, according to Medeiros et al. (2005). 
Table 1. Environmental conditions in the transport crates and in the climatized shed during the different lairage times in the slaughterhouse

\begin{tabular}{cccc}
\hline Transport crates / shed & Lairage times & $\begin{array}{c}\text { Temperature } \\
\left({ }^{\circ} \mathrm{C}\right)\end{array}$ & $\begin{array}{c}\text { Relative humidity } \\
(\%)\end{array}$ \\
\hline Top layer & 0 & 16.6 & 65 \\
Bottom layer & 0 & 15.1 & 71 \\
Shed & 0 & 13.4 & 51 \\
Top layer & 2 & 26.3 & 52 \\
Bottom layer & 2 & 24.9 & 55 \\
Shed & 2 & 18.1 & 51 \\
Top layer & 4 & 24.6 & 55 \\
Bottom layer & 4 & 22.7 & 51 \\
Shed & 4 & 23.1 & 51 \\
Top layer & 6 & 26 & 41 \\
Bottom layer & 6 & 25.8 & 42 \\
Shed & 6 & 26 & 55 \\
\hline
\end{tabular}

An evaluation of the position of crates in the truck revealed that the top layer presented the highest average temperatures. An explanation for this phenomenon is the principle of thermodynamics, whereby cold air tends to move downward because it is denser, thus reducing the temperature of the crates in lower layers, as Nazareno et al. (2013) found in their research into the transportation of fertile eggs.

A temperature gradient was also found between the microenvironment of the birds and the external environment, and the temperatures inside the crates were higher than or the same as those in the lairage shed, except for the crates transported in the bottom layer of the truck and subjected to four hours of lairage time. This is explained by the production of metabolic heat by the birds during transport, which was also observed by Mitchell and Kettlewell (1994), creating thermal heterogeneity between the transport crates and the climatized shed.

Table 2 lists the mean values of $\mathrm{pH}$ and color of the breast meat.

The different lairage times in the slaughterhouse and the positions of the crates in the truck did not affect the initial $\mathrm{pH}$ of the breast meat $(\mathrm{P}>0.05)$. As for the final $\mathrm{pH}$ levels, a significant difference $(\mathrm{P}<0.05)$ was found for the variable of lairage time, and the $\mathrm{pH}$ levels at 2, 4 and 6 hours of lairage time were higher than at zero lairage time. The position of the crates in the truck also significantly influenced the final $\mathrm{pH}$ of the samples $(\mathrm{P}<0.05)$, with the top layer presenting the highest value.

Stress factors, such as prolonged fasting time imposed on the birds in the experimental conditions, may have led to the depletion of muscle glycogen to maintain the energy needs of the bird's aerobic metabolism prior to slaughter. This results in meat with higher $\mathrm{pH}$ levels due to the low glycolysis rate (Zhang et al., 2009).

The mean values of $L^{*}$ measured at different lairage times showed significant differences, and the lowest values were found to correspond to the longer lairage times in the abattoir. The interaction factor was also significant. In terms of the time factor, the meat obtained after 4 and 6 hours of lairage time from birds transported in the top position in the truck, as well as those obtained after 4 hours of lairage from birds in the bottom position, presented lower values of luminosity than those obtained in the other conditions of the experiment. When comparing positions, the 6 hour lairage time and top position resulted in lower values than the same lairage time in the bottom position of the truck $(\mathrm{P}<0.05)$. These results are in agreement with those of Bianchi et al. (2006), who found lower values of luminosity when birds were subjected to lairage times of more than 6 hours in the slaughterhouse. This suggests that long lairage times at the slaughterhouse extend the total fasting time and favor the depletion of muscle glycogen, thus resulting in darker meat. 
Table 2. Average values of $\mathrm{pH}$ (initial - pHi and final - pHf) and color (L* - luminosity, $\mathrm{a}^{*}$ - red content and $b^{*}$ - yellow content) of the breasts of broilers subjected to different pre-slaughter lairage times and different crate positions in the truck

\begin{tabular}{|c|c|c|c|c|c|}
\hline Factors & $\mathrm{pHi}$ & $\mathrm{pHf}$ & $\mathrm{L}^{*}$ & $a^{*}$ & $\mathrm{~b}^{*}$ \\
\hline T0 & 6.39 & $5.9 \mathrm{~A}$ & $46.65 \mathrm{~A}$ & $-1.96 \mathrm{~A}$ & 6.41 \\
\hline $\mathrm{T} 2$ & 6.35 & $6.02 \mathrm{~B}$ & $44.42 \mathrm{AB}$ & $-3.35 \mathrm{~B}$ & 5.79 \\
\hline $\mathrm{T} 4$ & 6.32 & $6.07 \mathrm{~B}$ & $41.71 \mathrm{~B}$ & $0.04 \mathrm{C}$ & 6.28 \\
\hline T6 & 6.37 & $6.04 \mathrm{~B}$ & 42.91B & $0.58 \mathrm{C}$ & 6.37 \\
\hline $\mathrm{P} 1$ & 6.37 & $6.0 \mathrm{a}$ & $44.05 \mathrm{a}$ & $-0.57 \mathrm{a}$ & 5.79 \\
\hline $\mathrm{P} 2$ & 6.32 & $5.96 \mathrm{~b}$ & $43.79 \mathrm{a}$ & $-1.78 b$ & 6.13 \\
\hline T0xP1 & 6.42 & 5.94 & 47.79ABa & $-2.41 \mathrm{Ba}$ & 6.07 \\
\hline $\mathrm{T} 2 \mathrm{xP} 1$ & 6.34 & 6.04 & $45.54 \mathrm{ABCa}$ & $-2.31 \mathrm{Ba}$ & 4.71 \\
\hline $\mathrm{T} 4 \mathrm{xP} 1$ & 6.33 & 6.11 & $42.59 \mathrm{BCa}$ & $1.25 \mathrm{Aa}$ & 6.11 \\
\hline T6xP1 & 6.38 & 6.15 & $40.3 \mathrm{Cb}$ & $1.3 \mathrm{Aa}$ & 6.28 \\
\hline T0xP2 & 6.35 & 5.86 & $45.52 \mathrm{ABa}$ & $-1.52 \mathrm{Aa}$ & 6.74 \\
\hline $\mathrm{T} 2 \mathrm{xP} 2$ & 6.37 & 6.01 & $43.31 \mathrm{ABa}$ & $-4.4 \mathrm{Bb}$ & 4.87 \\
\hline $\mathrm{T} 4 \mathrm{xP2}$ & 6.3 & 5.99 & $40.83 \mathrm{Ba}$ & $-1.08 \mathrm{Ab}$ & 6.46 \\
\hline T6xP2 & 6.27 & 5.96 & $45.53 \mathrm{ABa}$ & $-0.14 \mathrm{Ab}$ & 6.45 \\
\hline Coefficient of variation $\%$ & 2.31 & 3.24 & 11.78 & 1.25 & 4.67 \\
\hline
\end{tabular}

Means followed by different letters differ statistically, according to the Tukey test $(\mathrm{p}<0.05)$.

Capital letters correspond to the comparisons of the Time factor in the columns. Lowercase letters correspond to comparisons of the crate Position factor in the columns.

T: Time; P1: Position of crates - top; P2: Position of crates - bottom, TxP: Time x Position interaction.

The values of $\mathrm{a}^{*}$ differed $(\mathrm{P}<0.05)$ between treatments, but these same factors did not influence the value of $b^{*} \quad(P>0.05)$. An evaluation of these results indicates that the birds that spent more time in the climatized shed and were transported in the top layer of the truck presented higher values of $\mathrm{a}^{*}$. The same applies to the birds transported in the top layer of the truck, associated with 4 and 6 hours of lairage time. The muscle with the highest final $\mathrm{pH}$ is able to retain a larger amount of water, and the resulting meat is dark $\left(<\mathrm{L}^{*}\right)$ and reddish $\left(>\mathrm{a}^{*}\right)$ due to lower light scattering at the surface (Petracci et al., 2004).

According to a Pearson correlation analysis, the final $\mathrm{pH}$ levels were negatively correlated with the value of $\mathrm{L}^{*}$. In this test, the negative correlation was -1.62 , indicating that the lower the $\mathrm{pH}$ of the chicken meat, the higher the value of L*. Quiao et al.'s study (2001) supports this finding because, in the same way, it demonstrates a significantly negative correlation between the color of broiler breast meat and the $\mathrm{pH}$ of the muscle.

The chicken breast quality was classified in the ranges of $\mathrm{L}^{*}$ and $\mathrm{pH}$ values, as proposed by
Barbut et al. (2005). Breast meat samples classified as dark, firm and dry are called DFD meat. These meats have a $\mathrm{pH}$ of $>6.1$ and $\mathrm{L}^{*}$ of $<46$, while meat classified as normal has a $\mathrm{pH}$ of $\leq 5.7$ to $\leq 6.1$. However, the $\mathrm{L}^{*}$ lies within the range of $\leq 46.0$ to $\leq 53$, and meats with $\mathrm{pH}$ of $<5.7$ and $\mathrm{L}^{*}$ of $>53.0$ are classified as pale, soft and exudative, or PSE. Thus, in this research, the interaction of the top layer of the crates in the truck and the lairage times of 4 and 6 hours provided favorable conditions for the development of DFD meat.

The incidence of DFD meat is higher in winter, when temperatures are below $0^{\circ} \mathrm{C}$, because stress engendered by cold causes energy expenditure to sustain muscle contractions motivated by energy demand (Dadgar et al., 2012). In this study, the temperatures reached in the lairage shed were no lower than $13.4^{\circ} \mathrm{C}$, indicating that the appearance of DFD meats can be attributed to factors other than low temperatures. Possibly, the increase in the chickens' total fasting time resulting from long lairage times in the abattoir caused an excessive consumption of their energy reserves, altering the biochemical transformation of the meat. 
Table 3 lists the hematological values of the erythrogram. As can be seen, the different lairage times in the slaughterhouse, the positions of the crates in the truck and their interactions did not significantly alter the hematological parameters of the erythrogram $(\mathrm{P}>0.05)$.

Table 3. Hematocrit (He), hemoglobin ( $\mathrm{Hb})$, hematocrit $(\mathrm{Ht})$ and total plasma protein (TPP) levels in broilers subjected to different pre-slaughter lairage times and different positions of the crates in the truck

\begin{tabular}{ccccc}
\hline Factors & $\begin{array}{l}\mathrm{He} \\
\left(10^{6} / \mu \mathrm{L}\right)\end{array}$ & $\mathrm{Hb}(\mathrm{g} / \mathrm{dL})$ & $\mathrm{Ht}(\%)$ & $\mathrm{TPP}(\mathrm{g} / \mathrm{dL})$ \\
\hline T0 & 2.48 & 8.17 & 30.5 & 4.10 \\
T2 & 2.63 & 8.46 & 32.62 & 3.70 \\
T4 & 2.55 & 8.15 & 31.25 & 4.35 \\
T6 & 2.45 & 8.58 & 34 & 4.15 \\
& & & & \\
P1 & 2.53 & 8.23 & 31.06 & 4.06 \\
P2 & 2.50 & 8.45 & 32.75 & \\
& & & & 3.80 \\
T0xP1 & 2.33 & 7.87 & 29 & 3.60 \\
T2xP1 & 2.49 & 8.07 & 30.25 & 4.35 \\
T4xP1 & 2.67 & 8.22 & 31 & \\
T6xP1 & 2.51 & 8.77 & 34 & 4.40 \\
T0xP2 & & & & 3.80 \\
T2xP2 & 2.63 & 8.47 & 32 & 4.15 \\
T4xP2 & 2.76 & 8.85 & 35 & 4.00 \\
T6xP2 & 2.43 & 8.07 & 32 & 11.35 \\
\hline
\end{tabular}

T: Time; P1: Position of crates - top; P2: Position of crates - bottom, TxP: Time x Position interaction.

Table 4 lists the absolute values of the leukogram, including total leukocytes, heterophils, lymphocytes, monocytes, eosinophils, basophils and heterophil/lymphocyte $(\mathrm{H} / \mathrm{L})$ ratio in broiler chickens.

Stress caused by transport and handling may lead to the release of endogenous corticosteroids, resulting in changes in CBC. Stress leukograms observed in mammals can also be found in birds, with the presence of augmented leukocytes and heterophils and decreased lymphocytes (Doneley, 2011). As for lymphocytes, the mean values declined significantly in response to longer lairage times ( 4 and 6 hours) $(\mathrm{P}<0.05)$. It is evident that the chronicity of stressful stimuli, such as long lairage times and the extension of total pre-slaughter fasting time, led to changes in the concentration of immunological cells in the blood of the broilers. These findings are similar to those reported by Altan et al. (2000), who investigated the hematological parameters of broilers in situations of stress.

The H/L ratio showed a significant difference $(\mathrm{P}<0.05)$ between the lairage times in the shed and interaction with the position in the truck. Stress caused by food and water restriction and thermal stress directly influence the $\mathrm{H} / \mathrm{L}$ ratio (Altan et al., 2000; Gross e Siegel, 1986). Confirming the statement of those authors, in this study it was found that a decrease in the number of lymphocytes, accompanied by an increase in the number of heterophils, resulted in an increase in the $\mathrm{H} / \mathrm{L}$ ratio in the birds that were subjected to 6 hours of lairage at the abattoir. This indicates that increasing the pre-slaughter lairage and fasting period generates stress-related metabolic disorders in broiler chickens.

The hematological analysis revealed significantly increase $(\mathrm{P}<0.05)$ basophil levels at lairage times of 4 and 6 hours. However, the number of eosinophils and monocytes were not influenced by the tested factors $(\mathrm{P}>0.05)$. Maxwell et al. (1990) reported that fasting-related stress may have been responsible for increased basophil counts as well as for declining eosinophil counts in chickens. Altan et al. (2000) suggested that basophilia can occur in situations of extreme stress, such as high temperatures in chickens during termination. 
Table 4. Absolute values $\left(\times 10^{3} / \mu \mathrm{L}\right)$ of leukocytes (Leu), heterophils (Het), lymphocytes (Lym), monocytes (Mon), eosinophils (Eos), basophils (Bas) and heterophil/lymphocyte (H/L) ratio in broilers subjected to different pre-slaughter lairage times and different positions of the crates in the truck

\begin{tabular}{cccccccc}
\hline Factors & Leu & Het & Lym & Mon & Eos & Bas & H/L \\
\hline T0 & $10.2 \mathrm{AB}$ & $3.5 \mathrm{AB}$ & $5.5 \mathrm{AB}$ & 1.7 & 0.2 & $7 \mathrm{~A}$ & $0.62 \mathrm{~A}$ \\
T2 & $11.7 \mathrm{~A}$ & $4.1 \mathrm{~A}$ & $6.9 \mathrm{~A}$ & 0.5 & 0.3 & $0 \mathrm{~A}$ & $0.63 \mathrm{~A}$ \\
T4 & $8.0 \mathrm{~B}$ & $2.8 \mathrm{~B}$ & $4.1 \mathrm{BC}$ & 1.1 & 0.2 & $177 \mathrm{~B}$ & $0.66 \mathrm{~A}$ \\
T6 & $9.6 \mathrm{AB}$ & $3.9 \mathrm{AB}$ & $3.6 \mathrm{C}$ & 0.6 & 0.2 & $79 \mathrm{AB}$ & $1.35 \mathrm{~B}$ \\
& & & & & & & \\
P1 & $8.8 \mathrm{a}$ & 2.9 & 4.4 & 0.7 & 0.2 & 69 & 0.84 \\
P2 & $10.9 \mathrm{~b}$ & 4.2 & 5.7 & 1.5 & 0.2 & 63 & 0.79 \\
& & & & & & & \\
T0xP1 & 8.8 & $2.2 \mathrm{Bb}$ & 5.2 & 0.6 & 0.2 & 15 & $0.44 \mathrm{Aa}$ \\
T2xP1 & 7.6 & $4.2 \mathrm{ABa}$ & 6.6 & 0.2 & 0.3 & 0 & $0.64 \mathrm{Aa}$ \\
T4xP1 & 7.0 & $1.8 \mathrm{Bb}$ & 4.0 & 0.8 & 0.3 & 186 & $0.43 \mathrm{Ab}$ \\
T6xP1 & 7.6 & $3.2 \mathrm{ABa}$ & 1.8 & 1.1 & 0.2 & 73 & $1.86 \mathrm{Ba}$ \\
& & & & & & & $0.81 \mathrm{Aa}$ \\
T0xP2 & 11.6 & $4.7 \mathrm{Aa}$ & 5.9 & 2.7 & 0.3 & 0 & $0.62 \mathrm{Aa}$ \\
T2xP2 & 11.4 & $4.0 \mathrm{Aa}$ & 7.1 & 0.9 & 0.2 & 0 & $0.89 \mathrm{Aa}$ \\
T4xP2 & 9.0 & $3.7 \mathrm{Aa}$ & 4.2 & 1.4 & 0.2 & 168 & $0.85 \mathrm{Ab}$ \\
T6xP2 & 11.6 & $4.5 \mathrm{Aa}$ & 5.4 & 1.2 & 0.2 & 85 & 12.20 \\
\hline Coefficient of variation $\%$ & 20.35 & 16.63 & 14.15 & 64.30 & 65.33 & 135.13 & \\
\hline
\end{tabular}

Means followed by different letters differ statistically, according to the Tukey test $(p<0.05)$.

Capital letters correspond to the comparisons of the Time factor in the columns. Lowercase letters correspond to comparisons of the crate Position factor in the columns.

T: Time; P1: Position of crates - top; P2: Position of crates - bottom, TxP: Time x Position interaction.

Table 5 lists the values of the serum biochemical parameters.

The plasma levels of biochemical metabolites found in this study indicate that the long fasting time caused by extending lairage times at the slaughterhouse altered the energy and lipid metabolism of broiler chickens. Although the plasma glucose level gradually decreased after 2 hours of lairage, a significant reduction $(\mathrm{P}<0.05)$ was observed in 6 hours of lairage time at the slaughterhouse. Presumably, glycogen degradation was unable to maintain the stability of the glycemic levels caused by excessive lairage and fasting times. The significant decrease in glucose concentrations is in agreement with Zhang et al. (2009) and Nijdam et al. (2005), who, upon subjecting chickens to the pre-slaughter steps and increasing their fasting times, found that the birds presented hypoglycemia resulting from the depletion of liver glycogen stores.

Enzymes such as CK and LDH have been proposed as sensitive indicators of stress in animals. The increase of these enzymes in the blood is considered an indication of skeletal muscle injuries and muscle fatigue caused by severe stress (Xing et al., 2015). In this experiment, higher enzymatic activity of CK $(\mathrm{P}<0.05)$ was observed in broilers transported in the top layer of the truck. These data indicate that the higher temperatures found in this position of the truck may have caused muscle discomfort in the birds.

The analyses showed that the chickens slaughtered at zero lairage time presented lower LDH activity $(\mathrm{P}<0.05)$ when compared to the other lairage times. It was also found that the effect of the top layer of the truck was to raise the levels of this enzyme $(\mathrm{P}<0.05)$. A significant difference $(\mathrm{P}<0.05)$ was also observed in the interaction, since the LDH levels were higher for the lairage times of 2 and 6 hours and the top position in the truck. The LDH results confirm the hypothesis proposed in this paper, i.e., that excessive lairage times in the slaughterhouse and prolonged fasting times lead to conditions detrimental to the birds' welfare. High plasma concentrations of this enzyme can serve to identify animals with muscle damage, and consequently a problem with meat quality (Marchi et al., 2012). 
Table 5. Mean glucose (Glu), creatine kinase (CK), lactate dehydrogenase (LDH), total cholesterol (Cho) and triglycerides (Tri) levels in broilers subjected to different pre-slaughter lairage times and different positions of the crates in the truck

\begin{tabular}{cccccc}
\hline Factors & $\begin{array}{c}\text { Glu } \\
(\mathrm{mg} / \mathrm{dL})\end{array}$ & $\begin{array}{c}\mathrm{CK} \\
(\mathrm{U} / \mathrm{L})\end{array}$ & $\begin{array}{c}\mathrm{LDH} \\
(\mathrm{mg} / \mathrm{dL})\end{array}$ & $\begin{array}{c}\text { Cho } \\
(\mathrm{mg} / \mathrm{dL})\end{array}$ & $\begin{array}{c}\text { Tri } \\
(\mathrm{ng} / \mathrm{dL})\end{array}$ \\
\hline T0 & $204 \mathrm{~A}$ & 27.2 & $20 \mathrm{~A}$ & $139 \mathrm{~A}$ & $57 \mathrm{~A}$ \\
T2 & $193 \mathrm{AB}$ & 27.3 & $35 \mathrm{~B}$ & $135 \mathrm{~A}$ & $49 \mathrm{AB}$ \\
T4 & $187 \mathrm{AB}$ & 24.3 & $38 \mathrm{~B}$ & $148 \mathrm{AB}$ & $47 \mathrm{~B}$ \\
T6 & $186 \mathrm{~B}$ & 26.5 & $30 \mathrm{AB}$ & $163 \mathrm{~B}$ & $47 \mathrm{~B}$ \\
& & & & & \\
P1 & 190 & $30.9 \mathrm{a}$ & $38 \mathrm{a}$ & 144 & 50 \\
P2 & 195 & $21.8 \mathrm{~b}$ & $24 \mathrm{~b}$ & 148 & 50 \\
& & & & & \\
T0xP1 & 195 & $26.4 \mathrm{Aa}$ & $16 \mathrm{Aa}$ & 137 & 54 \\
T2xP1 & 187 & $32 \mathrm{Aa}$ & $49 \mathrm{Ca}$ & 131 & 51 \\
T4xP1 & 189 & $33.2 \mathrm{Aa}$ & $53 \mathrm{Ca}$ & 145 & 45 \\
T6xP1 & 190 & $31.9 \mathrm{Aa}$ & $32 \mathrm{Ba}$ & 163 & 51 \\
& & & & & \\
T0xP2 & 213 & $28.1 \mathrm{ABa}$ & $24 \mathrm{Aa}$ & 141 & 60 \\
T2xP2 & 199 & $22.6 \mathrm{ABb}$ & $21 \mathrm{Ab}$ & 138 & 48 \\
T4xP2 & 186 & $15.5 \mathrm{Bb}$ & $23 \mathrm{Ab}$ & 152 & 50 \\
T6xP2 & 182 & $21.1 \mathrm{ABb}$ & $27 \mathrm{Aa}$ & 163 & 43 \\
Coefficient of & 5.46 & 17.31 & 19.63 & 18.83 & 13.68 \\
variation \% & & & & & \\
\hline
\end{tabular}

Means followed by different letters differ statistically, according to the Tukey test $(\mathrm{p}<0.05)$.

Capital letters correspond to the comparisons of the Time factor in the columns. Lowercase letters correspond to comparisons of the crate Position factor in the columns.

T: Time; P1: Position of crates - top; P2: Position of crates - bottom, TxP: Time x Position interaction.

In the above results, the lipid profiles of the chickens were found to differ significantly. The cholesterol levels were influenced by the lairage times at the slaughterhouse, with higher averages at 4 and 6 hours of lairage $(\mathrm{P}<0.05)$. It is assumed that the long pre-slaughter lairage times led to the release of lipids in broilers to obtain energy during fasting, as was also found in the experiment by Zhang et al. (2009).

As for triglyceride concentrations, there was a significant difference $(\mathrm{P}<0.05)$, with lower mean levels found in the birds subjected to 4 and 6 hour lairage times. Plasma triglyceride levels result from the ingestion of lipid diets or come from metabolic processes that lead to the formation of adipose tissue due to excess energetic substrate. Both of these sources are absent in birds subjected to pre-slaughter fasting (Nijdam et al., 2005), which explains the low triglyceride levels found after longer lairage times at the slaughterhouse. These observations are in agreement with the findings of Zhang et al. (2009), who showed that during pre-slaughter fasting, the glucose and triglyceride levels of chickens decline while their cholesterol levels increase.

\section{CONCLUSIONS}

Lairage times of more than 2 hours at the abattoir alter the metabolism of broiler chickens, influencing their energy and lipid profile and the immunological cells in blood and modifies the physical parameters of the meat.

\section{REFERENCES}

ALTAN, O.; ALTAN, A.; ÇABUK, M.; BAYRAKTAR, H. Effects of heat stress on some blood parameters in broilers. Turk. J. Vet. Anim. Sci., v.24, p.145-148, 2000.

BARBUT, S.; ZHANG, L.; MARCONE, L. Effects of pale, normal, and cooking of marinated fillets. Poult. Sci., v.84, p.797-802, 2005.

BIANCHI, M.; PETRACCI, M.; CAVANI, C. The influence of genotype, market live weight, transportation, and holding conditions prior to slaughter on broiler breast meat color. Poult. Sci., v.85, p.123-128, 2006 
BRASIL. Ministério da Agricultura, Pecuária e Abastecimento. Instrução Normativa $n^{\circ} 3$ de 17 de janeiro de 2000, aprova o regulamento técnico de métodos de insensibilização para abate humanitário de animais de açougue. Diário Oficial da União. Brasília, 24 jan. 2000. Seção 1, p.14.

BRASIL. Ministério da Agricultura, Pecuária e Abastecimento. Portaria $n^{\circ} 210$, de 10 de novembro de 1998, aprova o regulamento técnico da inspeção tecnológica e higiênico-sanitária de carne de aves. Diário Oficial da União, Brasília, 26 nov. de 1998; Seção 1, p.226..

BURKHOLDER, K.M.; THOMPSON, K.L.; EINSTEIN, M.E. Influence of stressors on normal intestinal microbiota, intestinal morphology, and susceptibility to Salmonella Enteritidis colonization in broilers. Poult. Sci., v.87, p.1734-1741, 2008

DADGAR, S.; LEE, E.S.; CROWE, T.G. et al. Characteristics of cold-induced dark, firm, dry broiler chicken breast meat. Br. Poult. Sci., v.53, p.351-359, 2012.

DONELEY B. Interpreting diagnostic tests. In: Avian medicine and surgery in practice: companion and aviary birds. London: Manson Publishing, 2011. p.69-91.

GROSS W.B.; SIEGEL P.B. Effects of initial and second periods of fasting on heterophil/lymphocyte ratios and body weight. Avian Dis., v.30, p.345-346, 1986.

KATO, T.; BARBOSA, C.F.; IDA, E.I. et al. Broiler chicken PSE (Pale, Soft, Exudative) meat and water release during chicken carcass thawing and Brazilian legislation. Braz. Arch. Biol. Technol., v.56, p.9961001,2013

LANGER, R.O.D.S.; SIMÕES, G.S.; SOARES, A.L. et al. Broiler transportation conditions in a Brazilian commercial line and the occurrence of breast PSE (Pale, Soft, Exudative) meat and DFD-like (Dark, Firm, Dry) meat. Braz. Arch. Biol. Technol, v.53, p.1161-1167, 2010.

LUDTKE, C.B.; CIOCCA, J.R.P.; DANDIN, T. Abate humanitário de aves. Copacabana: WSPA, 2010. $120 \mathrm{p}$.

MARCHI, D.F.; SANTILLI, J.C.; SOARES, A.L. et al. Atividades de creatina quinase e lactato desidrogenase na identificação de frangos com estresse e filés PSE (pale, soft, exudative). Semin. Ciênc. Agrár., v.33, supl.2, p.3103-3110, 2012.
MAXWELL, M.H.; ROBERTSON, G.W.; SPENCE, S.; Mc CORQUADALE, C.C. Comparison of haematological values in restricted and ad libitum-fed domestic fowls: white blood cells and thrombocytes. Br. Poult. Sci. v.31, p.399-405, 1990.

MEDEIROS, C.M.; BAÊTA, F.C.; OLIVEIRA, R.F.M. et al. Efeitos da temperatura, umidade relativa e velocidade do ar em frangos de corte. Eng. Agríc., v.13., p.277-286, 2005.

MITCHELL, M.A.; KETTLEWELL, P.J. Road transportion of broilers-chicken induction of physiological stress. World's Poult. Sci. J., v.50, p.5759, 1994.

NAZARENO, A.C.; SILVA, I.J.O.; VIEIRA, F.M.C. et al. Caracterização do microclima dos diferentes layouts de caixas no transporte de ovos férteis. Rev. Bras. Eng. Agríc. Ambiental, v.17, p.327-332, 2013.

NIJDAM, E.; ARENS, P.; LAMBOOIJ, E. et al. Factors influencing bruises and mortality of broilers during catching, transport, and lairage. Poult. Sci., v.83, p.1610-1615, 2004

NIJDAM, E.; DELEZIE, E.; LAMBOOIJ, E. Feed withdrawal of broilers before transport changes plasma hormone and metabolite concentrations. Poult. Sci., v.84, p.1146-1152, 2005.

PETRACCI, M.; BETTI, M.; BIANCHI, M. et al. Color variation and characterization of broiler breast meat during processing in Italy. Poult. Sci., v.83, p.2086-2092, 2004

QUIAO, M.; FLETCHER, D. L.; SMITH, D. P. et al. The effect of broiler breast meat color on $\mathrm{pH}$, moisture, water-holding capacity, and emulsification capacity. Poult. Sci., v.80, p.676-680, 2001.

VIEIRA, F.M.C.; SILVA, I.J.O.; BARBOSA FILHO, J.A.D. et al. Preslaughter mortality of broilers in relation to lairage and season in a subtropical climate. Poult. Sci., v.90, p.2127-2133, 2011.

XING, T.; XU, X.L.; ZHOU, G.H. et al. The effect of transportation of broilers during summer on the expression of heat shock protein 70, postmortem metabolism and meat quality. J. Anim. Sci., v.93, p.6270, 2015.

ZHANG, L.; YUE, H.Y.; ZHANG, H.J. et al. Transport stress in broilers: I. Blood metabolism, glycolytic potential, and meat quality. Poult. Sci., v.88, p.2033-2041, 2009. 